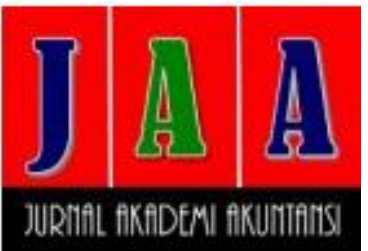

\section{THE EFFECT OF EMPLOYEE STOCK OPTION PLAN ON MARKET PERFORMANCE WITH FIRM PERFORMANCEAS INTERVENING VARIABLE}

\author{
Rachel Laudya*, Jesica Handoko, S.E., M.Si., Ak \\ Universitas Katolik Widya Mandala Surabaya \\ Jl. Dinoyo 42-44 Surabaya \\ *Corresponding author : rachel.laudya@gmail.com
}

Diterima : 24 Juli 2019

Direview : 25 Juli 2019

Direvisi : 06 November 2019

Diterima : 25 November 2019

Artikel ini tersedia di website : http://ejournal.umm.ac.id/index .php/jaa

\begin{abstract}
ABSTRAK
Employee Stock Option Plan (ESOP) merupakan surat kontrak dimana perusahaan akan memberikan hakkepada karyawannya untuk dapat membeli saham perusahaan dengan harga dan waktu tertentu. Program ini merupakan bentuk kompensasi yang dapat memotivasi serta menyelaraskan tujuan yang dinginkan oleh pihak prinsipal dan agen. Adanya kesamaan tujuan utama yang ingin dicapai akan memudahkan perusahaan dalam upaya peningkatan kinerja pasar perusahaan. Hubungan pengaruh antara ESOP dan kinerja pasar dapat dimediasi oleh variabel kinerja perusahaan yang diukur dengan return on asset dan return on equity. Kinerja perusahaan dapat menjadi sebuah jembatan dalam menunjukkan adanya pengaruh ESOP terhadap kinerja pasar.

Penelitian ini bersifat kuantitatif dengan menggunakan data sekunder yakni laporan tahunan, dalam menguji dan menganalisis pengaruh ESOP terhadap kinerja pasar dengan kinerja perusahaan sebagai variabel mediasi. Penelitian ini menggunakan keseluruhan perusahaan yang menerapkan ESOP dari semua sektor yang terdaftar di Bursa Efek Indonesia tahun 2010-2017. Sampel penelitian berjumlah 64 data sampel yang dipilih dengan teknik purposive sampling. Teknik analisis data menggunakan analisis jalur.

Hasil penelitian ini menunjukkan bahwa ESOP tidak memiliki pengaruh terhadap kinerja pasar perusahaan. ESOP tidak mempengaruhi kinerja perusahaan dengan pengukuran ROA namun memberikan pengaruh positif terhadap ROE. Dalam penelitian ini, kinerja perusahaan tidak mampu memediasi hubungan antara ESOP dan kinerja pasar.
\end{abstract}

Kata kunci : Employee Stock Option Plan, ESOP, kinerja perusahaan, kinerja pasar

\section{Introduction}

The similar problem that happened every year in Indonesia about minimum wage shouldn't happen. Syaikon (2014) stated that minimum wage assigned for the fresh employee, not for employees that have skill, ability and experience. They deserve to get a compensation that compatible with their given performance. 
According to Putra (2018), the enhancement of wages and the health insurance is not wrong, however it is not enough yet, the employees and companies need to consider the existence of employee stock option plan (ESOP). ESOP program is a contract that give the employee a chance to buy their own company's share with an amount and price that have been decided after or at expected date (Subramanyam, 2013:371). ESOP can play intermediary role in agency conflict. This conflict happened when the principal (owner, shareholders) and the agent (manager, employee ) in a company has different objective. By applying ESOP, the employees that given this opportunity will have the same objective with the principal, which is trying to get a dividend, as for that, the employees will attempt to increase the firm performance. The aligned objective will increase the employees' motivation because of they will feel more like a part of the company. The effect that will happen after the increasing motivation is that the increasing of firm performance because the firm performance is one of the tool to measure the employees' performance.

This research is focused on the effect of ESOP on firm performance (ROA and $\mathrm{ROE}$ ) and market performance with two main model, direct effect and indirect effect with firm performance as intervening variable between ESOP and market performance. ESOP can be expected to increase the feeling of employees as a part of a company and also having the aligned objective with the principal such as increasing profit. The employee increasing work can be reflected in how efficient and effective they are at using the company's asset (ROA) and equity (ROE), so as the firm performance increasing, the market performance will also be increased (Tobin's Q). This research object is all of the listed companies in Indonesia Stock Exchange that implemented ESOP between 2010-2017.

\section{Theoretical Framework and Hypothesis Development Agency theory}

Scott (2015:357) stated that the agency theory is a contract model between the principal and their agent, where the shareholders played a role as principal and the manager played as the agent. Shareholders are hoping that the management will work hard towards the company's objective as the shareholder's representative, but the reality says otherwise. The are several times where both parties has totally different objectives. Deegan (2014:281) explained that the agency theory doesn't assume that an individu can act other than in selfinterest, that is why the agent of a company will not do something or make a decision that did not give them a benefit or other than their self-interest. The principal, on the other hand should put a mechanisms that can align the objective between the employee and the company. Giving a company-related compensation or reward can be a solve for this problem.

Braendle and Rahdari (2016:11) stated that if the agent being reward on a basis that normally doesn't correlate to their effort then the agent won't have an initiative to give their best performance. The problem that now exist is how do a 
company make such as mechanisms so that the agent can act better (going for the same objective, giving the best effort) and be loyal to the principal (Kolb, 2012:31). The key solution is an assuring mechanism that give both side the same benefit by setting a proper compensation or reward benefited those sides. Deegan (2014:297) said that granting share options can increase longer focus of management so they can be motivated to work in their best effort for the company objective.

\section{Employee Stock Option}

Kieso et al, (2014:763) share option or mostly implemented with ESOP or the special option for management called Management Stock Option Plan (MSOP) is a long term compensation to increase the loyalty of the employees by giving them a piece of action which is the company's share. Suwardjono (2014:529) also stated that ESOP/MSOP is used by the company as a tool to increasing the loyalty and motivate the employees as an additional income or an additional compensation. ESOP is a contract between a company and its employees that give employees a right to buy a specific number of company's share with a fixed price in a certain period of time (Subramanyam, 2013:371). Giving this share option, according to Deegan (2014:297), will increase the management's long term focus as an agent and motivating them to give the company their optimal performance. This reward or compensation can align the objective between both sides.

The agent side who has company's share will have the higher ownership feeling towards the company so they will be more careful, thoughtful and responsible during their decision making that will effect the company. ESOP is structured to give a profit for the employees when the share price of the company in the market is much higher then the fixed price in the ESOP contract, they can buy it with a cheaper price and trade it with a higher price. The measurement for ESOP will be using the proportion by Ismail, Dockery and Ahmad (2017),

$$
\text { ESOP }=\frac{\text { Total of ESOP granted that year }}{\text { Total of Outstanding share of the year }}
$$

The application of this proportion is used based on the expectation that the amount of share granted for ESOP will reduce the agency conflict that happened between principal and agent so that the company's performance is expected to increase

\subsection{Market Performance}

Market performance of the company is also showed how good is the prospect that the company's had in the investor point of view. This research use Tobin's $Q$ as the tool to measure market performance. This measurement will compare the value market of the company with thier replacement cost. Tobin's $Q$ can measure the investor expection about the potential profit that the company will give them in the future (Stecker, 2009:132). This measurement is more 
independent and can reflect the market expection towards the company's performance because it didn't just use the information from one side (company in their financial report) but use the information by two side (company and market).

ESOP can help the principal to align the objective between the shareholders and their employee to increase the market performance, with this program employees will also have the objective to increase the company's market performance. When ESOP is granted by the company to their employees then the employees will have more motivation to give their best to increase the market performance. The employees is no longer have a role as employee but also have a role as a shareholder, that is why the employee will get a good amount of profit when the market perfomance is increasing.

\subsection{Company performance as an intervening variable}

The company performace is really important for the investor in deciding their investation decision. The performance can also be defined as an achievement of the company in certain period that also showed the health of the company. The increasing performance is also the objective that ESOP want to achieve. The principal believe that ESOP will give the initiative reaction from the employee to increase their own share value (Casson, 2012:86). This objective can be achieved when the employee showed their best performance that cna be relfected on the company's performance. The effect of ESOP for company performance will be measured with return on asset and return on equity. This measurement will show how efective the employee using the asset and the equity of the company to acive their profit.

Investor on the other side also use the company performance information to predict the profit that the company could give to them. Company performance can be a link between ESOP and market performance. Company performance has a role as an intervening variable in this research to show the connection between ESOP and market performance. Market can not directly see the effect of ESOP itself because employee performance won't be seen directly into the market. There is no report or detail information that can show the market about the employee's performance. Firm performance play a huge role here, because employee's performance can be relfected through the company performance.

H1a. ESOP have a positive impact towards the market performance with ROA as an intervening variable.

H1b. ESOP have a positive impact towards the market performance with ROE as an intervening variable

\section{Research Method}

\subsection{Research design}

This research is a qualitative research using the hypothesis examination. This design is used to show the impact of ESOP towards the market performance directly and also indirectly with company's performance as the 
intervening variable.

\subsection{Identification, Operational Definition and Variable Measurement}

\subsubsection{Independent Variable}

The independent variable used is ESOP. The measurement that is used is proportion between share granted for ESOP that year and the total of outstanding share that same year. This measurement is used following the previous research by Ismail, et al (2017),

$$
\text { ESOP }=\frac{\text { Total of share granted that year }}{\text { Total of outstanding share that year }}
$$

\subsubsection{Dependent Variable}

The dependent variable in this research is market performance. The measurement of this variable is using Tobin's $Q$ to show the comparison between market value of the company with its cost (Ismail, at al, 2017). The data that is used for this measurement is the stock price of the company at the end of the year that the share for ESOP is granted.

$$
\text { Tobin' }{ }^{\prime} \mathrm{Q}=\frac{\text { Total of share granted } \mathrm{x} \text { stock price at the end of the year }}{\text { Total of asset }}
$$

\subsubsection{Intervening Variable.}

This research is using company performance as its intervening variable. The company performance will be measured with return on asset and return on equity. These two ratio will describe the effectivity and efficiency of the company in using their own asset and equity in order to make the profit (Subramanyam., 2013:36).

Return on Asset (ROA) formula,

$$
\text { ROA }=\frac{\text { Net income after tax }}{\text { Total average of asset }}
$$

Return on Equity (ROE) formula,

$$
\text { ROA }=\frac{\text { Net income after tax }}{\text { Total average of equity }}
$$

\subsubsection{Control Variable}

Control variable is used in this research for show the difference between the company industry type and the size. The industry type will be distinguished into two type, finance industry and non- finance industry because the nature of the industry is totally difference. The industry type will 
be measured as the dummy variable, giving the number of 0 to the non-finance companies and 1 for the finance companies.

The company size will show how big is a company and will be measured with logarithm of their total asset. This measurement use the same formula as Ismail, et.al (2017).

$$
\text { Ln (Total Aset) }
$$

\subsection{Data Type and Resource}

This research use a secondary data from company's annual report that is listed in IDX and implementing the ESOP.

\subsection{Data Analysis}

Path analysis is used for this research to show the causality relation between its variable. The tool that is used is SPSS. The objective of this research is showing the relation of the ESOP proportion as the independent variable towards market performance directly and also indirectly with ROA and ROE as intervening variable.

\section{Result}

\subsection{General Description of The Research Data}

The object population is every companies that is listed in IDX in 20102017. Based on the criteria of purposive sampling that has been decided, there are 64 data that can be used for the object of this research.

\subsection{Data Description}

This research has an objective to show the relation of the ESOP proportion as the independent variable towards market performance directly and also indirectly with ROA and ROE as intervening variable The summary of the result from descriptive statistic is shown in the table 4.1.

Table 4.1

The result of descriptive statistic

\begin{tabular}{|l|c|c|c|c|c|}
\hline & $\mathrm{N}$ & Mean & Maximum & Minimum & Std. Deviation \\
\hline ESOP & 64 & $1,20242 \%$ & $9,809 \%$ & $0,002 \%$ & $1,476888 \%$ \\
\hline ROA & 64 & $5,2220 \%$ & $18,49 \%$ & $0,07 \%$ & $4,06344 \%$ \\
\hline ROE & 64 & $11,7641 \%$ & $29,20 \%$ & $0,50 \%$ & $6,97901 \%$ \\
\hline Tobin's Q & 64 & 0,99899 & 3,89399 & 0,10601 & 0,901581 \\
& & & & 6 & \\
\hline V.K. D & 64 & 0.31 & 1 & 0 & 0,467 \\
\hline LN_TA & 64 & 29,8705 & 33,22 & 26,77 & 1,43347 \\
\hline
\end{tabular}

Source : Data processed (2018), Appendix 2 


\subsection{Data Analysis}

The path analysis that is used can be measured with this relation :

The direct impact from ESOP to MP

The indirect impact from ESOP to MP with FP

Total of impact (correlation ESOP to MP)

$$
\begin{aligned}
& =\mathrm{p} 1 \\
& =\mathrm{p} 2 \times \mathrm{p} 3+ \\
& =\mathrm{p} 1+(\mathrm{p} 2 \times \mathrm{p} 3)
\end{aligned}
$$

The data analysis will be interpreted to these equation below :

$$
\begin{aligned}
& \mathrm{ROA}=\mathrm{b}_{0}+\mathrm{b}_{1} . \mathrm{ESOP}+\mathrm{b}_{3} . \mathrm{JI}_{\mathrm{i}}+\mathrm{b}_{4 . .} . \mathrm{TA}+\mathrm{e}_{\mathrm{i}} . \\
& \mathrm{ROE}=\mathrm{b}_{0}+\mathrm{b}_{1} \cdot \mathrm{ESOP}+\mathrm{b}_{3} . \mathrm{JI}_{\mathrm{i}}+\mathrm{b}_{4 .} . \mathrm{TA}+\mathrm{e}_{\mathrm{i}} \\
& \mathrm{MP}=\mathrm{b}_{0}+\mathrm{b}_{1} . \mathrm{ROA}_{\mathrm{i}}+\mathrm{b}_{2} . \mathrm{ROE}_{\mathrm{i}}+\mathrm{b}_{3} . \mathrm{ESOP}_{\mathrm{i}}+\mathrm{b}_{4 .} \mathrm{JI}_{\mathrm{i}}+\mathrm{b}_{5 .} . \mathrm{TA}+\mathrm{e}_{\mathrm{i}}
\end{aligned}
$$

Based on those 3 equation, these are the result from the tabulation :

\subsubsection{Classic Assumption Test}

\section{Normality Test}

The normality test can be seen from the unstandardized residual ignificance result that should be more than $5 \%$ or 0,005 to show that the data used is distributed normally.

Table 4.2

The result of Kolmogorov-Smirnov

\begin{tabular}{|c|l|c|c|c|}
\hline Equation & Information & $\begin{array}{l}\text { Monte Carlo } \\
\text { Sig. (2- } \\
\text { tailed) Sig. }\end{array}$ & $\begin{array}{l}\text { Monte Carlo } \\
\text { Sig. (2- tailed) } \\
\text { Upper Bound }\end{array}$ & Result \\
\hline 1a & $\begin{array}{c}\text { Unstandardized } \\
\text { Residual (ROA) }\end{array}$ & 0,594 & 0,714 & $\begin{array}{c}\text { Data normally } \\
\text { distributed }\end{array}$ \\
\hline $1 \mathrm{~b}$ & $\begin{array}{c}\text { Unstandardized } \\
\text { Residual (ROE) }\end{array}$ & 0,219 & 0,320 & $\begin{array}{c}\text { Data normally } \\
\text { distributed }\end{array}$ \\
\hline 2 & $\begin{array}{c}\text { Unstandardized } \\
\text { Residual }\end{array}$ & 0,469 & 0,591 & $\begin{array}{c}\text { Data normally } \\
\text { distributed }\end{array}$ \\
\hline
\end{tabular}

Source : Data processed (2018), Appendix 3

\section{Multicollinearity Test}

This test is used to make sure that there isn't any correlation between its variable in every equation used in this research. The result of this test will be shown from its variance inflation factor (VIF) and the tolerance value. The VIF should be less than 10 and the tolerance should be less than 1 . 
Table 4.3

The result of multicollinearity test

\begin{tabular}{|c|c|c|c|}
\hline Equation & Tolerance & VIF & Result \\
\hline 1a & & & \\
\hline ESOP & 0,875 & 1,143 & No multicollinearity \\
\hline V.K.D & 0,672 & 1,489 & No multicollinearity \\
\hline LN_TA & 0,624 & 1,603 & No multicollinearity \\
\hline 1b & & & \\
\hline ESOP & 0,875 & 1,143 & No multicollinearity \\
\hline V.K.D & 0,672 & 1,489 & No multicollinearity \\
\hline LN_TA & 0,624 & 1,603 & No multicollinearity \\
\hline 2 & & & \\
\hline ESOP & 0,793 & 1,216 & No multicollinearity \\
\hline V.K.D & 0,542 & 1,847 & No multicollinearity \\
\hline LN_TA & 0,567 & 1,763 & No multicollinearity \\
\hline ROA & 0,491 & 2,038 & No multicollinearity \\
\hline ROE & 0,549 & 1,823 & No multicollinearity \\
\hline Source $:$ Data & &
\end{tabular}

Source : Data processed (2018), Appendix 4

\section{Heteroscedasticity Test}

This test is used to show that there is dissimilarity variance from the residual of the whole data. The result will be showed in the significant value that should be more than 0,05 .

Table 4.4

Heteroscedasticity Test Result

\begin{tabular}{|c|c|c|}
\hline Variable & Sig. & Result \\
\hline ROA & 0,2363 & No Heteroscedasticity \\
\hline ROE & 0,0995 & No Heteroscedasticity \\
\hline Tobin's Q & 0,1155 & No Heteroscedasticity \\
\hline
\end{tabular}

Source : Data processed (2018), Appendix 6

\subsubsection{Model properness test}

The test is used to show the accuracy of the regression to describe the dependent variable in this research. The table below will show the result of this test. 
Table 4.6

Model properness test result

\begin{tabular}{|c|c|c|c|}
\hline Equation & Information & & Result \\
\hline 1a (ROA) & $R^{2}$ & 0,272 & \multirow{2}{*}{ The equation model is fit. } \\
\cline { 2 - 3 } & Sig & 0,000 & \multirow{2}{*}{ The equation model is fit. } \\
\hline \multirow{2}{*}{ 1b (ROE) } & $R^{2}$ & 0,186 & \multirow{2}{*}{ The equation model is fit. } \\
\cline { 2 - 3 } & Sig & 0,006 & \\
\hline 2 & $R^{2}$ & 0,527 & \multirow{2}{*}{ Then } \\
\cline { 2 - 3 } & Sig & 0,000 & \\
\hline
\end{tabular}

Source : Data processed (2018), appendix 7

1. Coefficient of Determination Test $\left(R^{2}\right)$

On the table 4.6, $R^{2}$ value is representing the ability of independent variable ESOP, industry type and company size explaining the dependent variable. The equation 1 a shows that the ability of the independent variables explaining the ROA is $27,2 \%$, meanwhile from equation $1 \mathrm{~b}$ shows that the independent variables explain $\mathrm{ROE}$ at $18,6 \%$. The equation model 2 with Tobin's $Q$ as the dependent variable, shows that the independent variables ability reach 52,7\% in explaining Tobin's $Q$.

2. F Statistic Test

The result from this test is concluded based on the significance value from every equation that should be lower than 0,05 so that the equation model can be a fit regression model. Table 4.6 shows that every equation model has its significance lower than 0,05 that can be concluded, every regression model in this research is fit.

3. Statistic t Test

This test is used to show the significance impact between each variable that will be shown on table 4.7 below;

Table 4.7 Result of statistic $t$ test

\begin{tabular}{|c|c|c|c|c|}
\hline \multicolumn{5}{|c|}{ Dependent Variable : ROA (Regression 1) } \\
\hline Independent Variable & $\mathrm{B}$ & $\mathrm{Sig}$ & Result & R Square \\
\hline ESOP & 0,109 & 0,737 & Have no impact & \\
\cline { 1 - 4 } $\begin{array}{c}\text { Variabel dummy sektor } \\
\text { industri }\end{array}$ & $-4,024$ & 0,001 & Negative impact & \multirow{2}{*}{0,272} \\
\hline LN_Total Aset & $-0,268$ & 0,501 & Have no impact & \\
\hline
\end{tabular}




\begin{tabular}{|c|c|c|c|c|}
\hline \multicolumn{5}{|c|}{ Dependent Variable: ROE (Regression 2) } \\
\hline Independent Variable & $\mathrm{B}$ & Sig & Result & R Square \\
\hline ESOP & 0,079 & 0,030 & Positive impact & \multirow{3}{*}{0,186} \\
\hline $\begin{array}{c}\text { Variabel dummy sektor } \\
\text { industri }\end{array}$ & $-0,422$ & 0,002 & Negative impact & \\
\hline LN_Total Aset & 0,067 & 0,128 & Have no impact & \\
\hline \multicolumn{5}{|c|}{ Dependent Variable : Tobin's Q (Regression 3) } \\
\hline Independent Variable & B & Sig & Result & R Square \\
\hline ESOP & $-0,093$ & 0,140 & Have no impact & \multirow{5}{*}{0,527} \\
\hline $\begin{array}{c}\text { Variabel dummy sektor } \\
\text { industri }\end{array}$ & $-0,408$ & 0,091 & Have no impact & \\
\hline LN_Total Aset & $-0,124$ & 0,106 & Have no impact & \\
\hline ROA & 0,117 & 0,000 & Positive impact & \\
\hline ROE & $-0,229$ & 0,382 & Have no impact & \\
\hline
\end{tabular}

Source : Data processed (2018), appendix 8

From the table 4.7 shows some result that can be summarize as below ;

1. ESOP has no impact towards ROA with significance value at 0,737 that is higher than it should be $(0,05)$, so do company size that has significance value at 0,501 . The industry type has negative impact towards ROA.

2. From the regression 2 test result can be shown that ESOP has a positive impact towards ROE which means that the higher ESOP proportion that a company's had will also increase the ROE of the company. Meanwhile the industry type gives negative impact on ROE and company size has no impact towards ROE.

3. Result of the test in regression 3 shows that all the independent variables has no impact towards Tobin's $Q$ except ROA. ROA has a positive impact that is shown in the significance value which is below 0,05. It shows that the higher of ROA that a company achieve will also increase the market performance of the company.

\subsubsection{Path Analysis}

This analysis will show the cause and effect relation between each variable that is used in this research directly and indirectly. This following equation is used in path analysis ;

Equation 1

$$
\begin{aligned}
& \mathrm{FP}=\mathrm{b}_{0}+\mathrm{b}_{1} . \mathrm{ESOP}+\mathrm{b}_{3} . \mathrm{JI}_{\mathrm{i}}+\mathrm{b}_{4 .} . \mathrm{TA}+\mathrm{e}_{\mathrm{i}} \\
& \mathrm{ROA}=\mathrm{b}_{0}+\mathrm{b}_{1} \cdot \operatorname{ESOP}+\mathrm{b}_{3} . \mathrm{JI}_{\mathrm{i}}+\mathrm{b}_{4 .} . \mathrm{TA}+\mathrm{e}_{\mathrm{i}} \\
& \mathrm{ROA}=14,341+\text { 0, 109.ESOP }-4,024 . \mathrm{JI}_{\mathrm{i}^{-}} \text {0,268. TA }+\mathrm{e}_{\mathrm{i}} \\
& \mathrm{ROE}=\mathrm{b}_{0}+\mathrm{b}_{1} \cdot \operatorname{ESOP}+\mathrm{b}_{3} . \mathrm{JI}_{\mathrm{i}}+\mathrm{b}_{4 .} . \mathrm{TA}+\mathrm{e}_{\mathrm{i}}
\end{aligned}
$$




$$
\mathrm{ROE}=-1,032+\text { 0,079.ESOP }- \text { 0,422. } \mathrm{JI}_{\mathrm{i}}+\text { 0,067. TA }+\mathrm{e}_{\mathrm{i}}
$$

Equation 2

$$
\begin{aligned}
& \mathrm{MP}=\mathrm{b}_{0}+\mathrm{b}_{2} . \mathrm{ESOP}_{\mathrm{i}}+\mathrm{b}_{3} . \mathrm{JI}_{\mathrm{i}}+\mathrm{b}_{4 .} . \mathrm{TA}+\mathrm{e}_{\mathrm{i}} \\
& \mathrm{MP}=4,545+0,117 . \mathrm{ROA}_{\mathrm{i}}-0,229 . \mathrm{ROE}_{\mathrm{i}} \mathrm{0}, 98 . \mathrm{ESOP}_{\mathrm{i}}-0,782 . \mathrm{JI}_{\mathrm{i}}-0,171 . \\
& \mathrm{TA}+\mathrm{e}_{\mathrm{i}}
\end{aligned}
$$

The following will show the schema result from path analysis,

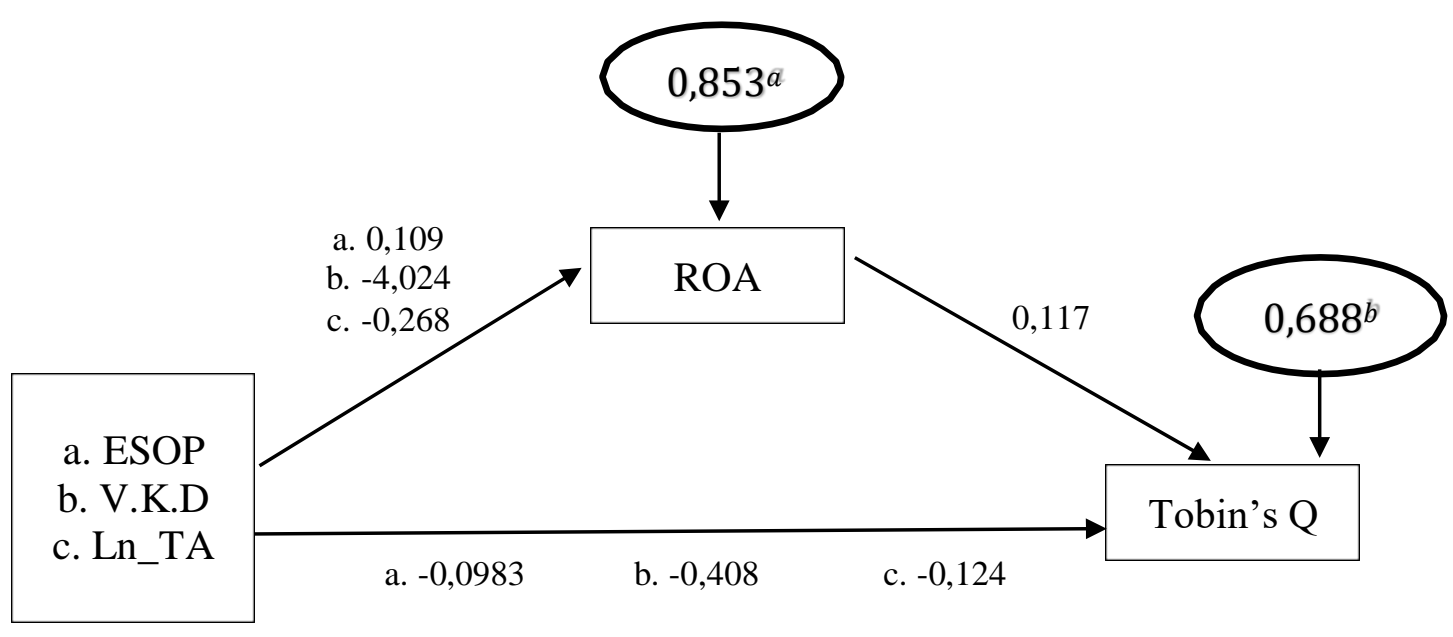

Schema 4.1. Path Analysis ROA

Explanation :

a : Calculation of

$$
\begin{aligned}
& \sqrt{1-\text { Rsquared regresi } 1 \text { tabel }} 4.8 \\
& =\sqrt{1-0,272} \\
& =0,853 \\
& \sqrt{1-\text { Rsquared regresi } 3 \text { tabel } 4} .8 \\
& =\sqrt{1-0,527} \\
& =0,688
\end{aligned}
$$

$\mathrm{b}:$ Calculation of 


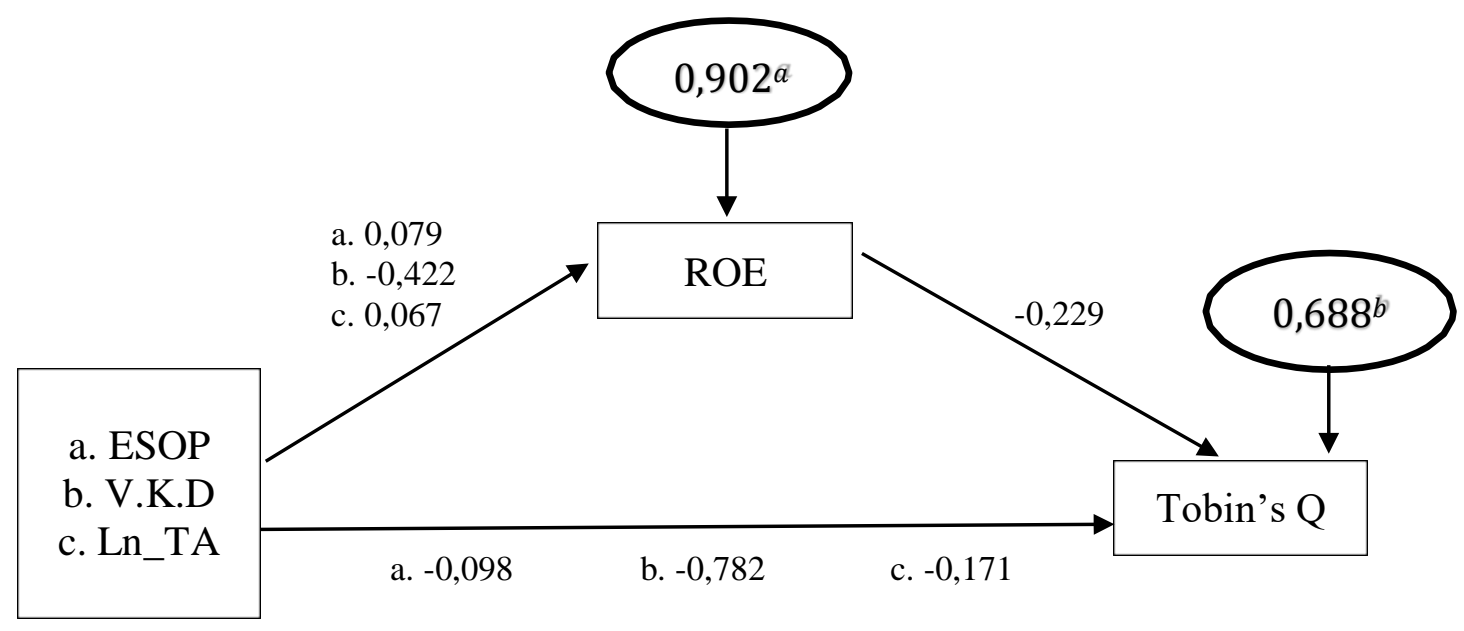

Schema 4.2. Path Analysis ROE

Explanation :

$\mathrm{a}:$ Calculation of

$$
\begin{aligned}
& \sqrt{1-\text { Rsquared regresi } 2 \text { tabel } 4.8} \\
= & \sqrt{1-0,186} \\
= & 0,902
\end{aligned}
$$

$\mathrm{b}$ : Calculation of

$$
\begin{aligned}
& \sqrt{1-\text { Rsquared regresi } 3 \text { tabel } 4.8} \\
& =\sqrt{1-0,527} \\
& =0,688
\end{aligned}
$$

This following formula is used to find out the impact value between ESOP towards market performance directly and with ROA as intervening variable;

$$
\begin{array}{ll}
\text { Direct impact between ESOP towards MP } & =-0,098 \\
\text { Indirect impact from ESOP to ROA towards MP } & =0,109 \times 0,117 \\
\text { Total impact (correlation ESOP towards MP) } & =-0,098+(0,109 \times 0,117)
\end{array}
$$

As stated above, the indirect impact from ESOP towards market performance with ROA as intervening variable is bigger than the direct impact. This result is shown from the direct comparison between -0,098 which is smaller than the result of $0,109 \times 0,117=0,013$. Meanwhile the result of $-0,098+0,013$ is $-0,085$ shows the total impact directly and indirectly from ESOP towards market performance with ROA as intervening.

This following formula is used to find out the impact value between ESOP towards 
market performance directly and with ROA as intervening variable;

Direct impact from ESOP towards MP $=-0,098$

Indirect impact between ESOP to ROE towards MP $\equiv 0,079 \mathrm{x}-0,229$

Total impact (correlation ESOP towards MP) $=-0,098+(0,079 \mathrm{x}-0,229)$

As stated above, the indirect impact from ESOP towards market performance with ROE as intervening variable is bigger than the direct impact. This result is shown from the direct comparison between -0,098 which is smaller than the result of $0,079 \times-0,229=-0,02$. Meanwhile the result of $-0,098-0,02$ is $-0,118$ shows the total impact directly and indirectly from ESOP towards market performance with ROE as intervening.

\subsubsection{Sobel Test}

Sobel test is used to show the ability of the intervening variable as a mediator between ESOP and market performance. The impact between ESOP towards tobin's $Q$ with ROA as intervening can be count with the formula below:

$$
\mathrm{Sab}=\sqrt{\mathrm{b}^{2} S \mathrm{a}^{2}+\mathrm{a}^{2} \mathrm{Sb}^{2}+\mathrm{Sa}^{2}} \mathrm{Sb}^{2}
$$

Result :

$$
\begin{aligned}
& =\sqrt{(0,117)^{2}(0,324)^{2}+(0,109)^{2}(0,029)^{2}+(0,324)^{2}(0,029)^{2}} \\
& =0,039
\end{aligned}
$$

The result then used to count the $t$ that will be compared to the $t$ table to get a conclusion ;

$$
\mathrm{t}=\frac{0,117 \times 0,109}{0,039}=0,327
$$

From the $t$ count above, the result of 0,327 will be compared to the $t$ table with significance value 0,05 which is 1,96 . If the $t$ count is lower than the table then can be concluded that the hypothesis in this research is rejected, in other words can be explained that the variable used as intervening can be an intervening between the independent variable and dependent variable. The result for this research showed that ROA can not play a role as an intervening variable between ESOP and market performance. The impact between ESOP towards tobin's $Q$ with ROE as intervening can be count with the formula below:

$$
\begin{aligned}
& =\sqrt{(-0,229)^{2}(0,036)^{2}+(0,079)^{2}(0,260)^{2}+(0,036)^{2}(0,260)^{2}} \\
& =0,021
\end{aligned}
$$


The result then used to count the $t$ that will be compared to the $t$ table to get a conclusion ;

$$
\begin{aligned}
t & =\frac{0,079 x-0,229}{0,021} \\
& =-0,861
\end{aligned}
$$

From the $t$ count above, the result of $-0,861$ will be compared to the $t$ table with significance value 0,05 which is 1,96 . The result for this research showed that ROE can not play a role as an intervening variable between ESOP and market performance.

\subsection{Explanation}

\subsubsection{The indirect impact of ESOP towards market performance with company performance as intervening variable.}

ESOP that should be a tool that can help a company to motivate their employees to maximize the market performance of the company so that they can get much profit towards it is not proven in this research. This result is align with the research made by Ismail,et al (2017). ESOP in fact seen to has a higher risk when compared to the cash bonus that is more familiar to the employees because they can directly get the advantage or benefit without waiting, even though ESOP actually will give them a long- term benefit. The existence of terms for employee to get ESOP, also making it more complicated for employees to understand how ESOP actually works and benefitted them. Moreover, ESOP is not a booming program in Indonesia, is showed from the least companies that implemented this program. This indicates that in market performance ESOP will not be an important or crucial factors to value a company. Furthermore, the fact than the stock option is giving a right for employees to buy or not also need to be taken as a consideration. Employees in the internal part than knows how the companies actually works, from the risk until the future prospect of the company. ESOP won't play any role when the employees has an information about the high risk of the company because at the end they won't redeem the ESOP granted for them. That is why ESOP also has no impact towards the market performance.

The impact between ESOP to ROA cannot be proven in this research, this is shows that the proportion of ESOP won't make a higher ROA for the company. ROA also can be proven to play a role as an intervening variable for ESOP towards market performance. Meanwhile ROA has a direct impact towards market performance with the ESOP effect that showed the higher ROA of a company will also increase the market performance of the company. This result 
is align with the result of Ismail, et al (2017), Ismiyanthi and Mahadwartha (2017), Dewi and Hatane (2015) research that show ESOP has no impact towards ROA.

This research showed that ESOP has a positive impact towards company performance measured by ROE which means that the higher proportion of ESOP granted in a company will also increase the effective and efficiency of company in using their equity to achieve their profit. This result showed that ESOP can give the ownership feeling to their employees and motivate employees to increase their performance in managing the equity of the company to get profit. However, from the test result before showed that $\mathrm{ROE}$ is not proven to be an intervening variable between ESOP and market performance. This conclusion is showed from the sobel test result done before. From that result the second hypothesis in this research is also cannot be proven because company performance cannot play a role as an intervening variable between ESOP towards market performance.

This can be happened considering the low ESOP proportion given by the company that cannot maximize the ownership feeling in the employee's mindset. The very low proportion given cannot motivate employees to give their best towards the company because after all, they won't also get maximize advantage from that (Ismail, et al, 2017). Hallock, Salazar, \& Venneman (2004) stated that ownership portion that is granted to ESOP will give a significant impact to how the employees giving their performance to increase the company performance because there will be a difference between ownership and controlling.

\section{Conclusion, Implication and Limitation}

\subsection{Conclusion}

1. Employee Stock Option Plan has no impact towards market performance. This conclusion showed that the ESOP proportion in the company will not give a significant impact towards the market performance of a company. This is caused by the unpopular ESOP in Indonesia that made employees and market is not so used of this program, which means that whether employees and market has no enough information about hoe ESOP works and benefited them.

2. Company performance is not proven to play a role as an intervening variable between ESOP and market performance. ESOP has no significant impact towards company performance measured by ROA but has a positive impact towards ROE which means that the higher ESOP proportion granted will also increase the ROE of the company.

\subsection{Limitations}

This research has limitations as followed:

1. The difficulty to look for the list of company implementing ESOP in Indonesia. There isn't any list that showed all companies implementing ESOP in the period decided in this research making a main hurdle so that 
cannot be confirmed that all the companies implementing ESOP has already be the object of this research.

2. This research also didn't separate the type of ESOP that is used in companies so that cannot be shown which type of ESOP that actually give an impact.

3. The measurement of company performance in this research also using only two measurement ROA and ROE. The data that is used is also at the same year when the ESOP is granted so that the impact after that year cannot be shown.

4. This research also using Tobin's $Q$ that is using data at the end of the year that cannot directly represent the impact between ESOP directly after its granted towards the dependent variable.

\subsection{Implication}

Based on the limitations stated above, these are the implication given for the next research :

1. The next researcher can make a deep searching towards the exact list of companies implementing ESOP in Indonesia, so that every companies implementing ESOP can be the object of the research.

2. The next research also expected to separate and identificate the types of ESOP used so that can show which type that can give an impact towards dependent variables used.

3. The next research is also expected to add more measurement of company performance and longer period of observation so that can include a broader view.

4. The next research is expected to use the data near at the granted day of the ESOP to show the direct impact after the ESOP granted.

\section{References}

Breandle, U.C., dan Rahdari A.H. 2016. The theory and practice of direction's remuration: new challenges and oppurtunities. United Kingdom : Emerald Group Publishing Limited.

Casson, P. 2012. Business performance excellence. United Kingdom : Bloomsbury Information Ltd.

Deegan, C. 2014. Financial accounting theory (edisi ke-4). Australia :

McGraw-Hill Education Pty Ltd.

Dewi, Y.T dan Hatane, S.E. 2015. Peranan ESOP dalam Pengaruh VAIC terhadap Financial Performance. Bussiness Accounting Review, 3(1), 478-488.

Hallock,D.E., Salazar,R.J., dan Venneman, S. 2004. Demographic and Attitudinal Correlates of Employee Satisfication with an ESOP. British Journal of Management, 15(4), 321-333

Ismail, Z., Dockery, E., dan Ahmad, A.S. 2017. Does Stock Option Plan Really 
Matter on the Malaysian Firm Performance ?. Journal of Contemporary Issues and Thought, 7, 104-118.

Ismiyanti, F., dan Mahadwartha. P.A. 2017. Does Employee Stock Ownership Plan Matter? An Emperical Note. Investment Management and Financial Innovation, 14(3), 381-388

Kieso, D.E., Weygandt, J,J., dan Warfield, T.D. 2014. Intermediate Accounting IFRS edition. (edisi ke-2). New Jersey : John Wiley dan Sons Inc.

Kolb, R.W. 2012. Too much is not enough : incentives ini executives compensation. United States : Oxford University

Oktaresa, B. (2017) Mengukur Kinerja Perusahaan dengan Tobin's $Q$. Didapat dari www.kompasiana.com/betrikaoktaresa/594d532beec6ec2c437c0282/men gukur-kinerja-perusahaan- dengan-tobin-s-q, 10 September, pukul 11:34 WIB

Putra, H. 2018. Keadilan, Demokrasi dan Saham untuk Karyawan. Didapat dari www.ekonomi.kompas.com/read/2018/05/02/074214926/keadilandemokrasi-dan-saham-untuk- karyawan, 1 September 2018, pukul 13:30 WIB.

Scott, W. 2015. Financial Accounting Theory (edisi ke-7). Toronto : Pearson.

Stecker, N. 2009. Innovation strategy and firm performance. An empirical study of publicy listed firms. (edisi ke- 1). Germany : Gabler.

Subramanyam, K, R. 2013. Financial Statement Analysis (edisi ke-11). New York : NY McGraw Hill Education. Suwardjono. 2014. Teori akuntansi, perekayasaan pelaporan keuangan (edisi ke-3). Yogyakarta : BFEYogyakarta.

Syaikon, A. 2014. Tuntutan Buruh Untuk Kenaikan UMR-Oleh Sembodo Cahyanto Kunto, Pemerhati Masalah Perburuhan. Didapat dari www.neraca.co.id/article/45688/tuntutan-buruh-untuk-kenaikan-umroleh- sembodo-cahyanto-kunto-pemerhati-masalah-perburuhan, 29 Agustus 2018, pukul 12:45 WIB.

Trisna, R, N., dan Astika, I.B.P. (2018). Pengaruh Employee Stock Option Plan pada Kinerja Perusahaan dan Implikasinya pada Return Saham. E-Jurnal Akuntansi Universitas Udayana, 22 (2), 831-855.

\section{Appendix}

\section{Appendix 1. Data Sample}

\begin{tabular}{|c|c|l|c|c|}
\hline No. & Code & \multicolumn{1}{|c|}{ Company Name } & Year & ESOP type \\
\hline 1 & AGII & Aneka Gas Industri Tbk & 2016 & MESOP \\
\hline 2 & AGRS & PT. Bank Agris Tbk & 2014 & ESA \\
\hline 3 & AKRA & PT. AKR Corporindo & 2010 & MSOP \\
\hline
\end{tabular}




\begin{tabular}{|c|c|c|c|c|}
\hline 4 & AKRA & PT. AKR Corporindo & 2011 & MSOP \\
\hline 5 & AKRA & PT. AKR Corporindo & 2012 & MSOP \\
\hline 6 & AKRA & PT. AKR Corporindo & 2013 & MSOP \\
\hline 7 & AKRA & PT. AKR Corporindo & 2014 & MSOP \\
\hline 8 & AKRA & PT. AKR Corporindo & 2015 & MSOP \\
\hline 9 & APII & Arita Prima Indonesia Tbk & 2014 & MESOP \\
\hline 10 & APII & Arita Prima Indonesia Tbk & 2015 & MESOP \\
\hline 11 & APLN & Agung Podomoro Land Tbk & 2011 & MESOP \\
\hline 12 & APLN & Agung Podomoro Land Tbk & 2012 & MESOP \\
\hline 13 & APLN & Agung Podomoro Land Tbk & 2013 & MESOP \\
\hline 14 & APLN & Agung Podomoro Land Tbk & 2014 & MESOP \\
\hline 15 & APLN & Agung Podomoro Land Tbk & 2015 & MESOP \\
\hline 16 & APLN & Agung Podomoro Land Tbk & 2016 & MESOP \\
\hline 17 & ASSA & Adi Sarana Armada Tbk & 2012 & ESA \\
\hline 18 & ATIC & Anabatic Technologies Tbk & 2016 & MESOP \\
\hline 19 & BABP & Bank MNC Internasional Tbk & 2016 & MESOP \\
\hline 20 & BBTN & Bank Tabungan Negara Tbk & 2010 & MESOP \\
\hline 21 & BBTN & Bank Tabungan Negara Tbk & 2011 & MESOP \\
\hline 22 & BBTN & Bank Tabungan Negara Tbk & 2012 & MESOP \\
\hline 23 & BCAP & MNC Kapital Indonesia Tbk & 2012 & MESOP \\
\hline 24 & BCAP & MNC Kapital Indonesia Tbk & 2013 & MESOP \\
\hline 25 & BCAP & MNC Kapital Indonesia Tbk & 2014 & MESOP \\
\hline 26 & BDMN & Bank Danamon Indonesia Tbk & 2015 & MSOP \\
\hline 27 & BHIT & MNC Investama Tbk & 2010 & MESOP \\
\hline 28 & BHIT & MNC Investama Tbk & 2011 & MESOP \\
\hline 29 & BHIT & MNC Investama Tbk & 2012 & MESOP \\
\hline 30 & BHIT & MNC Investama Tbk & 2014 & MESOP \\
\hline 31 & BHIT & MNC Investama Tbk & 2016 & MESOP \\
\hline 32 & BJTM & Bank Pembangunan Daerah Jawa Timur & 2015 & MESOP \\
\hline 33 & BJTM & Bank Pembangunan Daerah Jawa Timur & 2016 & MESOP \\
\hline 34 & BJTM & Bank Pembangunan Daerah Jawa Timur & 2017 & MESOP \\
\hline 35 & BMTR & Global Mediacom Tbk & 2011 & EMSOP \\
\hline 36 & BMTR & Global Mediacom Tbk & 2014 & EMSOP \\
\hline 37 & BMTR & Global Mediacom Tbk & 2016 & EMSOP \\
\hline 38 & BNGA & Bank CIMB Niaga Tbk & 2017 & ESOP \\
\hline 39 & BOLT & Garuda Metalindo Tbk & 2015 & ESA \\
\hline 40 & BTPN & Bank Tabungan Pensiunan Nasional & 2015 & MESOP \\
\hline 41 & BWPT & Eagle High Plantations Tbk & 2011 & ESOP \\
\hline 42 & BWPT & Eagle High Plantations Tbk & 2010 & ESOP \\
\hline 43 & BWPT & Eagle High Plantations Tbk & 2012 & ESOP \\
\hline 44 & DPUM & Dua Putra Utama Makmur Tbk & 2015 & ESA \\
\hline
\end{tabular}




\begin{tabular}{|c|c|l|r|c|}
\hline 45 & DSNG & Dharma Satya Nusantara Tbk & 2014 & ESOP \\
\hline 46 & KINO & Kino Indonesia Tbk & 2015 & ESA \\
\hline 47 & KPIG & MNC Land Tbk & 2016 & MESOP \\
\hline 48 & KPIG & MNC Land Tbk & 2017 & MESOP \\
\hline 49 & KPIG & MNC Land Tbk & 2012 & MESOP \\
\hline 50 & KPIG & MNC Land Tbk & 2014 & MESOP \\
\hline 51 & KPIG & MNC Land Tbk & 2013 & MESOP \\
\hline 52 & KPIG & MNC Land Tbk & 2011 & MESOP \\
\hline 53 & MNCN & Media Nusantara Citral Tbk & 2012 & MESOP \\
\hline 54 & MNCN & Media Nusantara Citral Tbk & 2016 & MESOP \\
\hline 55 & MNCN & Media Nusantara Citral Tbk & 2010 & MESOP \\
\hline 56 & MNCN & Media Nusantara Citral Tbk & 2011 & MESOP \\
\hline 57 & MNCN & Media Nusantara Citral Tbk & 2010 & MESOP \\
\hline 58 & NIKL & Pelat Timah Nusantara Tbk & MESOP \\
\hline 59 & SDRA & Bank Woori Saudara Indonesia & 2013 & MSOP \\
\hline 60 & SKBM & Sekar Bumi Tbk & 2014 & MSOP \\
\hline 61 & SKBM & Sekar Bumi Tbk & 2014 & MESOP \\
\hline 62 & WSKT & Waskita Karya Tbk & 2014 & EESOP \\
\hline 63 & WSKT & Waskita Karya Tbk & \\
\hline 64 & WTON & Wijaya Karya Beton Tbk & \\
\hline
\end{tabular}

Information :

$\mathrm{ESOP}=$ Employee Stock

Option Plan MSOP =

Management Stock

Option Plan ESA =

Employee Stock

Allocation

MESOP = Management and Employee Stock Option Plan

EMSOP = Employee and Management Stock Option Plan

Appendix 2. Descriptive Statistics Result

Descriptive Statistics

\begin{tabular}{|l|r|r|r|r|r|}
\hline & $\mathrm{N}$ & \multicolumn{1}{|c|}{ Minimum } & Maximum & Mean & Std. Deviation \\
\hline ESOP & 64 & $0.002 \%$ & $9.809 \%$ & $1.20242 \%$ & $1.476888 \%$ \\
ROA & 64 & $0.07 \%$ & $18.49 \%$ & $5.2220 \%$ & $4.06344 \%$ \\
ROE & 64 & $0.50 \%$ & $29.20 \%$ & $11.7641 \%$ & $6.97901 \%$ \\
Tobin's Q & 64 & .106016852070 & 3.89399025696 & .998991551104 & .901581195654 \\
& & 1703 & 53135 & 024 & 862 \\
V.K. D & 64 & 0 & 1 & .31 & .467 \\
LN_TA & 64 & 26.77 & 33.22 & 29.8705 & 1.43347 \\
Valid N (listwise) & 64 & & & \\
\hline
\end{tabular}


Appendix 3. Normality test result

\begin{tabular}{|c|c|c|c|c|c|}
\hline & & & $\begin{array}{c}\text { Unstandardize } \\
\text { d Residual }\end{array}$ & $\begin{array}{c}\text { Unstandardiz } \\
\text { ed Residual }\end{array}$ & $\begin{array}{c}\text { Unstandardiz } \\
\text { ed Residual }\end{array}$ \\
\hline $\mathrm{N}$ & & & 64 & 64 & 64 \\
\hline Normal & Mean & & .0000000 & .0000000 & - 0000000 \\
\hline Parameters $^{\mathrm{a}, \mathrm{b}}$ & Std. Deviation & & 3.46745283 & .38149931 & .62028808 \\
\hline Most Extreme & Absolute & & .099 & .145 & .120 \\
\hline Differences & Positive & & .099 & .068 & .120 \\
\hline & Negative & & -.071 & -.145 & -.069 \\
\hline Test Statistic & & & .099 & .145 & .120 \\
\hline Asymp. Sig. (2- & -tailed) & & $.193^{\mathrm{c}}$ & $.002^{\mathrm{c}}$ & $.023^{\mathrm{c}}$ \\
\hline Monte Carlo & Sig. & & $.594^{\mathrm{d}}$ & $.219^{\mathrm{d}}$ & $.469^{\mathrm{d}}$ \\
\hline Sig. (2-tailed) & Confidence & Lower Bound & .473 & .117 & .346 \\
\hline & Interval & Upper Bound & .714 & .320 & .591 \\
\hline
\end{tabular}

a. Test distribution is Normal.

b. Calculated from data.

c. Lilliefors Significance Correction.

d. Based on 64 sampled tables with starting seed 2000000 .

e. This is a lower bound of the true significance.

\section{Appendix 4. Multicollinearity test result}

\section{Coefficients $^{\mathrm{a}}$}

\begin{tabular}{|c|c|c|c|c|c|c|c|}
\hline \multirow[b]{2}{*}{ Model } & \multicolumn{2}{|c|}{$\begin{array}{l}\text { Unstandardized } \\
\text { Coefficients }\end{array}$} & \multirow{2}{*}{$\begin{array}{c}\begin{array}{c}\text { Standardized } \\
\text { Coefficients }\end{array} \\
\text { Beta }\end{array}$} & \multirow[b]{2}{*}{$\mathrm{t}$} & \multirow[b]{2}{*}{ Sig. } & \multicolumn{2}{|c|}{ Collinearity Statistics } \\
\hline & B & Std. Error & & & & Tolerance & VIF \\
\hline 1 (Constant) & 14.341 & 11.755 & & 1.220 & .227 & & \\
\hline ESOP & .109 & .324 & .040 & .338 & .737 & .875 & 1.143 \\
\hline V.K. D & -4.024 & 1.169 & -.463 & -3.442 & .001 & .672 & 1.489 \\
\hline LN_TA & -.268 & .395 & -.094 & -.677 & .501 & .624 & 1.603 \\
\hline
\end{tabular}

a. Dependent Variable: ROA

Coefficients $^{\mathrm{a}}$

\begin{tabular}{|c|c|c|c|c|c|c|c|}
\hline \multirow[b]{2}{*}{ Model } & \multicolumn{2}{|c|}{$\begin{array}{l}\text { Unstandardized } \\
\text { Coefficients }\end{array}$} & \multirow{2}{*}{$\begin{array}{c}\begin{array}{c}\text { Standardized } \\
\text { Coefficients }\end{array} \\
\text { Beta }\end{array}$} & \multirow[b]{2}{*}{$\mathrm{t}$} & \multirow[b]{2}{*}{ Sig. } & \multicolumn{2}{|c|}{ Collinearity Statistics } \\
\hline & B & Std. Error & & & & Tolerance & VIF \\
\hline 1 (Constant) & -1.032 & 1.293 & & -.798 & .428 & & \\
\hline ESOP & .079 & .036 & .277 & 2.224 & .030 & .875 & 1.143 \\
\hline V.K. D & -.422 & .129 & -.467 & -3.285 & .002 & .672 & 1.489 \\
\hline LN_TA & .067 & .043 & .228 & 1.544 & .128 & .624 & 1.603 \\
\hline
\end{tabular}

a. Dependent Variable: LG_ROE 
Coefficients $^{\mathrm{a}}$

\begin{tabular}{|c|c|c|c|c|c|c|c|}
\hline \multirow[b]{2}{*}{ Model } & \multicolumn{2}{|c|}{$\begin{array}{l}\text { Unstandardized } \\
\text { Coefficients }\end{array}$} & \multirow{2}{*}{$\begin{array}{c}\begin{array}{c}\text { Standardized } \\
\text { Coefficients }\end{array} \\
\text { Beta }\end{array}$} & \multirow[b]{2}{*}{$\mathrm{t}$} & \multirow[b]{2}{*}{ Sig. } & \multicolumn{2}{|c|}{ Collinearity Statistics } \\
\hline & $\mathrm{B}$ & Std. Error & & & & Tolerance & VIF \\
\hline 1 (Constant) & 4.545 & 2.223 & & 2.045 & .045 & & \\
\hline ESOP & -.093 & .062 & -.152 & -1.496 & .140 & .793 & 1.261 \\
\hline V.K. D & -.408 & .237 & -.211 & -1.721 & .091 & .542 & 1.847 \\
\hline LN_TA & -.124 & .075 & -.197 & -1.644 & .106 & .567 & 1.763 \\
\hline ROA & .117 & .029 & .528 & 4.093 & .000 & .491 & 2.038 \\
\hline LG_ROE & -.229 & 260 & -.108 & -.882 & .382 & .549 & 1.823 \\
\hline
\end{tabular}

a. Dependent Variable: Tobin's Q

\section{Appendix 5. Heteroskedasticity test result}

Heteroskedasticity Test: Glejser

\begin{tabular}{llll}
\hline \hline F-statistic & 9.327547 & Prob. F(3,60) & 0.0000 \\
Obs*R-squared & 20.35503 & Prob. Chi-Square(3) & 0.0001 \\
Scaled explained SS & 19.68471 & Prob. Chi-Square(3) & 0.0002 \\
\hline
\end{tabular}

Test Equation:

Dependent Variable: ARESID

Method: Least Squares

Date: 01/12/18 Time: 22:52

Sample: 164

Included observations: 64

\begin{tabular}{lllll}
\hline \multicolumn{1}{c}{ Variable } & Coefficient & Std. Error & t-Statistic & Prob. \\
\hline C & 2.411364 & 0.653872 & 3.687824 & 0.0005 \\
\multicolumn{1}{c}{ ESOP } & -0.051263 & 0.018022 & -2.844474 & 0.0061 \\
V_K_D & 0.325450 & 0.065030 & 5.004570 & 0.0000 \\
\multicolumn{1}{c}{ LN_TA } & -0.072049 & 0.021992 & -3.276121 & 0.0018 \\
\hline R-squared & 0.318047 & Mean dependent var & 0.299274 \\
Adjusted R-squared & 0.283950 & S.D. dependent var & 0.233570 \\
S.E. of regression & 0.197647 & Akaike info criterion & -0.344211 \\
Sum squared resid & 2.343850 & Schwarz criterion & -0.209281 \\
Log likelihood & 15.01476 & Hannan-Quinn criter. & -0.291056 \\
F-statistic & 9.327547 & Durbin-Watson stat & 1.626031 \\
Prob(F-statistic) & 0.000038 & & & \\
\hline
\end{tabular}


Heteroskedasticity Test: Glejser

\begin{tabular}{llll}
\hline \hline F-statistic & 3.524108 & Prob. F(3,60) & 0.0202 \\
Obs*R-squared & 9.587736 & Prob. Chi-Square(3) & 0.0224 \\
Scaled explained SS & 10.15342 & Prob. Chi-Square(3) & 0.0173 \\
\hline
\end{tabular}

Test Equation:

Dependent Variable: ARESID

Method: Least Squares

Date: 01/12/18 Time: 22:50

Sample: 164

Included observations: 64

\begin{tabular}{lrlrl}
\hline \hline \multicolumn{1}{c}{ Variable } & Coefficient & Std. Error & t-Statistic & Prob. \\
\hline C & 9.847040 & 6.944007 & 1.418063 & 0.1613 \\
ESOP & -0.089758 & 0.191390 & -0.468979 & 0.6408 \\
V_K_D & -1.376321 & 0.690613 & -1.992899 & 0.0508 \\
LN_TA & -0.223216 & 0.233554 & -0.955733 & 0.3430 \\
\hline \hline R-squared & 0.149808 & Mean dependent var & 2.641448 \\
Adjusted R-squared & 0.107299 & S.D. dependent var & 2.221538 \\
S.E. of regression & 2.098973 & Akaike info criterion & 4.381235 \\
Sum squared resid & 264.3412 & Schwarz criterion & 4.516165 \\
Log likelihood & -136.1995 & Hannan-Quinn criter. & 4.434391 \\
F-statistic & 3.524108 & Durbin-Watson stat & 1.195374 \\
Prob(F-statistic) & 0.020187 & & \\
\hline
\end{tabular}

Heteroskedasticity Test: Glejser

\begin{tabular}{llll}
\hline F-statistic & 3.810042 & Prob. F(5,58) & 0.0047 \\
Obs*R-squared & 15.82362 & Prob. Chi-Square(5) & 0.0074 \\
Scaled explained SS & 18.56844 & Prob. Chi-Square(5) & 0.0023 \\
\hline
\end{tabular}

Test Equation:

Dependent Variable: ARESID

Method: Least Squares

Date: 01/12/18 Time: 22:41

Sample: 164

Included observations: 64

\begin{tabular}{crrrr}
\hline Variable & Coefficient & Std. Error & t-Statistic & Prob. \\
\hline C & 1.212473 & 1.322798 & 0.916597 & 0.3631 \\
ESOP & -0.005000 & 0.036860 & -0.135646 & 0.8926 \\
V_K_D & -0.241690 & 0.140993 & -1.714203 & 0.0918 \\
LN_TA & -0.026020 & 0.044895 & -0.579580 & 0.5644
\end{tabular}




\begin{tabular}{lrlrr}
\multicolumn{1}{c}{ ROA } & 0.029678 & 0.017028 & 1.742846 & 0.0867 \\
\multicolumn{1}{c}{ LG_ROE } & -0.064940 & 0.154770 & -0.419587 & 0.6763 \\
\hline R-squared & 0.247244 & Mean dependent var & 0.447813 \\
Adjusted R-squared & 0.182351 & S.D. dependent var & 0.425486 \\
S.E. of regression & 0.384741 & Akaike info criterion & 1.016566 \\
Sum squared resid & 8.585475 & Schwarz criterion & 1.218961 \\
Log likelihood & -26.53011 & Hannan-Quinn criter. & 1.096300 \\
F-statistic & 3.810042 & Durbin-Watson stat & 2.366603 \\
Prob(F-statistic) & 0.004724 & &
\end{tabular}

Heteroskedasticity Test: White

\begin{tabular}{llll}
\hline F-statistic & 1.420475 & Prob. F(3,60) & 0.2456 \\
Obs*R-squared & 4.244090 & Prob. Chi-Square(3) & 0.2363 \\
Scaled explained SS & 6.218541 & Prob. Chi-Square(3) & 0.1014 \\
\hline
\end{tabular}

Test Equation:

Dependent Variable: RESID^2

Method: Least Squares

Date: 01/12/18 Time: 23:02

Sample: 164

Included observations: 64

\begin{tabular}{crrrr}
\hline \multicolumn{1}{c}{ Variable } & Coefficient & Std. Error & t-Statistic & Prob. \\
\hline \multicolumn{1}{c}{ C } & 16.57915 & 35.10934 & 0.472215 & 0.6385 \\
ESOP^2 & -0.040590 & 0.226904 & -0.178887 & 0.8586 \\
V_K_D^2 & -11.69662 & 7.292605 & -1.603902 & 0.1140 \\
LN_TA^2 & -0.001054 & 0.040290 & -0.026165 & 0.9792 \\
\hline R-squared & 0.066314 & Mean dependent var & 11.83537 \\
Adjusted R-squared & 0.019630 & S.D. dependent var & 21.78197 \\
S.E. of regression & 21.56712 & Akaike info criterion & 9.040679 \\
Sum squared resid & 27908.44 & Schwarz criterion & 9.175609 \\
Log likelihood & -285.3017 & Hannan-Quinn criter. & 9.093834 \\
F-statistic & 1.420475 & Durbin-Watson stat & 1.401235 \\
Prob(F-statistic) & 0.245637 & & \\
& & &
\end{tabular}

Heteroskedasticity Test: Harvey

\begin{tabular}{llll}
\hline F-statistic & 2.181570 & Prob. F(3,60) & 0.0995 \\
Obs*R-squared & 6.294436 & Prob. Chi-Square(3) & 0.0981 \\
Scaled explained SS & 4.923316 & Prob. Chi-Square(3) & 0.1775 \\
\hline
\end{tabular}

Test Equation:

Dependent Variable: LRESID2

Method: Least Squares 
Date: 01/12/18 Time: 23:14

Sample: 164

Included observations: 64

\begin{tabular}{crlrr}
\hline \multicolumn{1}{c}{ Variable } & Coefficient & Std. Error & t-Statistic & Prob. \\
\hline C & 16.26673 & 6.374144 & 2.551987 & 0.0133 \\
ESOP & -0.370181 & 0.175683 & -2.107090 & 0.0393 \\
V_K_D & 0.789908 & 0.633937 & 1.246035 & 0.2176 \\
LN_TA & -0.449648 & 0.214388 & -2.097359 & 0.0402 \\
\hline R-squared & 0.098351 & Mean dependent var & 2.637254 \\
Adjusted R-squared & 0.053268 & S.D. dependent var & 1.980182 \\
S.E. of regression & 1.926720 & Akaike info criterion & 4.209976 \\
Sum squared resid & 222.7350 & Schwarz criterion & 4.344907 \\
Log likelihood & -130.7192 & Hannan-Quinn criter. & 4.263132 \\
F-statistic & 2.181570 & Durbin-Watson stat & 1.448411 \\
Prob(F-statistic) & 0.099504 & & \\
\hline
\end{tabular}

Heteroskedasticity Test: White

\begin{tabular}{llll}
\hline F-statistic & 1.859556 & Prob. F(5,58) & 0.1155 \\
Obs*R-squared & 8.842162 & Prob. Chi-Square(5) & 0.1155 \\
Scaled explained SS & 14.41890 & Prob. Chi-Square(5) & 0.0132 \\
\hline
\end{tabular}

Test Equation:

Dependent Variable: RESID ${ }^{\wedge} 2$

Method: Least Squares

Date: 01/12/18 Time: 23:04

Sample: 164

Included observations: 64

\begin{tabular}{crrrr}
\hline \multicolumn{1}{c}{ Variable } & Coefficient & Std. Error & t-Statistic & Prob. \\
\hline C & 1.234595 & 1.213507 & 1.017378 & 0.3132 \\
ESOP^2 & -0.000199 & 0.007945 & -0.025080 & 0.9801 \\
ROA^2 & 0.002994 & 0.001812 & 1.651956 & 0.1039 \\
LG_ROE^2 & -0.194051 & 0.191339 & -1.014175 & 0.3147 \\
V_K_D^2 & -0.308014 & 0.260981 & -1.180215 & 0.2427 \\
LN_TA^2 & -0.000766 & 0.001390 & -0.550591 & 0.5840 \\
\hline R-squared & 0.138159 & Mean dependent var & 0.378745 \\
Adjusted R-squared & 0.063862 & S.D. dependent var & 0.760713 \\
S.E. of regression & 0.736022 & Akaike info criterion & 2.313947 \\
Sum squared resid & 31.42026 & Schwarz criterion & 2.516342 \\
Log likelihood & -68.04630 & Hannan-Quinn criter. & 2.393681 \\
F-statistic & 1.859556 & Durbin-Watson stat & 2.286583 \\
Prob(F-statistic) & 0.115545 & & \\
\hline
\end{tabular}


Appendix 6. Model

properness test result

\begin{tabular}{|c|c|c|c|c|c|c|c|c|c|}
\hline & & & & I Summary & & & & & \\
\hline \multirow[b]{2}{*}{$\begin{array}{l}\text { Mod } \\
\text { el }\end{array}$} & \multirow[b]{2}{*}{$\mathrm{R}$} & \multirow[b]{2}{*}{$\begin{array}{c}\mathrm{R} \\
\text { Square }\end{array}$} & \multirow[b]{2}{*}{$\begin{array}{l}\text { Adjusted R } \\
\text { Square }\end{array}$} & \multirow[b]{2}{*}{$\begin{array}{l}\text { Std. Error of } \\
\text { the Estimate }\end{array}$} & \multicolumn{5}{|c|}{ Change Statistics } \\
\hline & & & & & $\begin{array}{l}\text { R Square } \\
\text { Change }\end{array}$ & $\begin{array}{c}\mathrm{F} \\
\text { Change }\end{array}$ & df1 & df2 & $\begin{array}{c}\text { Sig. F } \\
\text { Change }\end{array}$ \\
\hline 1 & $.521^{\mathrm{a}}$ & .272 & .235 & $3.55308 \%$ & .272 & 7.466 & 3 & 60 & .000 \\
\hline
\end{tabular}

a. Predictors: (Constant), LN_TA, ESOP, V.K. D

ANOVA $^{\mathrm{a}}$

\begin{tabular}{|ll|r|r|r|r|r|}
\hline Model & & Sum of Squares & df & Mean Square & F & Sig. \\
\hline 1 & Regression & 282.762 & 3 & 94.254 & 7.466 & $.000^{\mathrm{b}}$ \\
& Residual & 757.463 & 60 & 12.624 & & \\
& Total & 1040.226 & 63 & & & \\
\hline
\end{tabular}

a. Dependent Variable: ROA

b. Predictors: (Constant), LN_TA, ESOP, V.K. D

Coefficients $^{\mathrm{a}}$

\begin{tabular}{|l|r|r|r|r|r|r|r|}
\hline \multirow{2}{*}{ Model } & \multicolumn{2}{|c|}{$\begin{array}{c}\text { Unstandardized } \\
\text { Coefficients }\end{array}$} & $\begin{array}{c}\text { Standardized } \\
\text { Coefficients }\end{array}$ & \multicolumn{1}{c|}{$\mathrm{t}$} & \multicolumn{2}{c|}{ Sig. } & \multicolumn{2}{|c|}{ Collinearity Statistics } \\
\cline { 2 - 8 } & \multicolumn{1}{c|}{$\mathrm{B}$} & Std. Error & \multicolumn{1}{c|}{ Beta } & & & Tolerance & VIF \\
\hline 1 (Constant) & 14.341 & 11.755 & & 1.220 & .227 & & \\
ESOP & .109 & .324 & .040 & .338 & .737 & .875 & 1.143 \\
V.K. D & -4.024 & 1.169 & -.463 & -3.442 & .001 & .672 & 1.489 \\
LN_TA & -.268 & .395 & -.094 & -.677 & .501 & .624 & 1.603 \\
\hline
\end{tabular}

a. Dependent Variable: ROA

Model Summary

\begin{tabular}{|c|c|c|c|c|c|c|c|c|c|}
\hline \multirow[b]{2}{*}{$\begin{array}{l}\text { Mod } \\
\text { el }\end{array}$} & \multirow[b]{2}{*}{$\mathrm{R}$} & \multirow[b]{2}{*}{$\begin{array}{c}\mathrm{R} \\
\text { Square }\end{array}$} & \multirow[b]{2}{*}{$\begin{array}{c}\text { Adjusted R } \\
\text { Square }\end{array}$} & \multirow[b]{2}{*}{$\begin{array}{l}\text { Std. Error of } \\
\text { the Estimate }\end{array}$} & \multicolumn{5}{|c|}{ Change Statistics } \\
\hline & & & & & $\begin{array}{l}\text { R Square } \\
\text { Change }\end{array}$ & $\begin{array}{c}\text { F } \\
\text { Change }\end{array}$ & $\begin{array}{c}\mathrm{df} \\
1\end{array}$ & df 2 & $\begin{array}{c}\text { Sig. F } \\
\text { Change }\end{array}$ \\
\hline 1 & $.431^{\mathrm{a}}$ & .186 & .145 & .39092 & .186 & 4.574 & 3 & 60 & .00 \\
\hline
\end{tabular}

a. Predictors: (Constant), LN_TA, ESOP, V.K. D

ANOVA $^{\mathrm{a}}$

\begin{tabular}{|ll|r|r|r|r|r|}
\hline Model & & Sum of Squares & df & Mean Square & F & Sig. \\
\hline 1 & Regression & 2.097 & 3 & .699 & 4.574 & $.006^{\mathrm{b}}$ \\
& Residual & 9.169 & 60 & .153 & & \\
& Total & 11.266 & 63 & & & \\
\hline
\end{tabular}

a. Dependent Variable: LG_ROE

b. Predictors: (Constant), LN_TA, ESOP, V.K. D 
Coefficients $^{\mathrm{a}}$

\begin{tabular}{|c|c|c|c|c|c|c|c|}
\hline \multirow[t]{2}{*}{ Model } & \multicolumn{2}{|c|}{$\begin{array}{l}\text { Unstandardized } \\
\text { Coefficients }\end{array}$} & \multirow{2}{*}{$\begin{array}{c}\begin{array}{c}\text { Standardized } \\
\text { Coefficients }\end{array} \\
\text { Beta }\end{array}$} & \multirow[t]{2}{*}{$\mathrm{t}$} & \multirow[t]{2}{*}{ Sig. } & \multicolumn{2}{|c|}{ Collinearity Statistics } \\
\hline & B & Std. Error & & & & Tolerance & VIF \\
\hline 1 (Constant) & -1.032 & 1.293 & & -.798 & .428 & & \\
\hline ESOP & .079 & .036 & .277 & 2.224 & .030 & .875 & 1.143 \\
\hline V.K. D & -.422 & .129 & -.467 & -3.285 & .002 & .672 & 1.489 \\
\hline LN_TA & .067 & .043 & .228 & 1.544 & .128 & .624 & 1.603 \\
\hline
\end{tabular}

a. Dependent Variable: LG_ROE

Model Summary

\begin{tabular}{|c|c|c|c|c|c|c|c|c|c|}
\hline \multirow[b]{2}{*}{$\begin{array}{l}\text { Mod } \\
\text { el }\end{array}$} & \multirow[b]{2}{*}{$\mathrm{R}$} & \multirow[b]{2}{*}{$\begin{array}{c}\mathrm{R} \\
\text { Square }\end{array}$} & \multirow[b]{2}{*}{$\begin{array}{l}\text { Adjusted R } \\
\text { Square }\end{array}$} & \multirow[b]{2}{*}{$\begin{array}{l}\text { Std. Error of } \\
\text { the Estimate }\end{array}$} & \multicolumn{5}{|c|}{ Change Statistics } \\
\hline & & & & & $\begin{array}{l}\text { R Square } \\
\text { Change }\end{array}$ & $\begin{array}{c}\mathrm{F} \\
\text { Change }\end{array}$ & $\begin{array}{c}\mathrm{df} \\
1\end{array}$ & df2 & $\begin{array}{c}\text { Sig. F } \\
\text { Change }\end{array}$ \\
\hline 1 & $.604^{\mathrm{a}}$ & .364 & .333 & $\begin{array}{r}.7365852254 \\
10701\end{array}$ & .364 & 11.462 & 3 & 60 & .000 \\
\hline
\end{tabular}

a. Predictors: (Constant), LN_TA, ESOP, V.K. D

ANOVA $^{\mathrm{a}}$

\begin{tabular}{|ll|r|r|r|r|r|}
\hline Model & & Sum of Squares & df & Mean Square & F & Sig. \\
\hline 1 & Regression & 18.656 & 3 & 6.219 & 11.462 & $.000^{\mathrm{b}}$ \\
& Residual & 32.553 & 60 & .543 & & \\
& Total & 51.209 & 63 & & & \\
\hline
\end{tabular}

a. Dependent Variable: Tobin's Q

b. Predictors: (Constant), LN_TA, ESOP, V.K. D

Coefficients $^{\mathrm{a}}$

\begin{tabular}{|l|r|r|r|r|r|r|r|}
\hline \multirow{2}{*}{ Model } & \multicolumn{2}{|c|}{$\begin{array}{c}\text { Unstandardized } \\
\text { Coefficients }\end{array}$} & $\begin{array}{c}\text { Standardized } \\
\text { Coefficients }\end{array}$ & \multicolumn{1}{c|}{$\mathrm{t}$} & \multicolumn{2}{|c|}{ Sig. } & \multicolumn{2}{|c|}{ Collinearity Statistics } \\
\cline { 2 - 8 } & \multicolumn{1}{c|}{$\mathrm{B}$} & Std. Error & Beta & & & Tolerance & VIF \\
\hline 1 (Constant) & 6.461 & 2.437 & & 2.651 & .010 & & \\
ESOP & -.098 & .067 & -.161 & -1.459 & .150 & .875 & 1.143 \\
V.K. D & -.782 & .242 & -.405 & -3.227 & .002 & .672 & 1.489 \\
LN_TA & -.171 & .082 & -.271 & -2.083 & .042 & .624 & 1.603 \\
\hline
\end{tabular}

a. Dependent Variable: Tobin's Q

Model Summary

\begin{tabular}{|c|c|c|c|c|c|c|c|c|c|}
\hline \multirow[b]{2}{*}{$\begin{array}{l}\text { Mod } \\
\text { el }\end{array}$} & \multirow[b]{2}{*}{$\mathrm{R}$} & \multirow[b]{2}{*}{$\begin{array}{c}\mathrm{R} \\
\text { Square }\end{array}$} & \multirow[b]{2}{*}{$\begin{array}{c}\text { Adjusted R } \\
\text { Square }\end{array}$} & \multirow[b]{2}{*}{$\begin{array}{l}\text { Std. Error of } \\
\text { the Estimate }\end{array}$} & \multicolumn{5}{|c|}{ Change Statistics } \\
\hline & & & & & $\begin{array}{l}\text { R Square } \\
\text { Change }\end{array}$ & $\begin{array}{c}\text { F } \\
\text { Change }\end{array}$ & $\begin{array}{c}\mathrm{df} \\
1\end{array}$ & $\mathrm{df} 2$ & $\begin{array}{l}\text { Sig. F } \\
\text { Change }\end{array}$ \\
\hline 1 & $.726^{\mathrm{a}}$ & .527 & .486 & $\begin{array}{r}.6464719920 \\
53314\end{array}$ & .527 & 12.906 & 5 & 58 & .000 \\
\hline
\end{tabular}

a. Predictors: (Constant), LG_ROE, LN_TA, ESOP, V.K. D, ROA 
ANOVA $^{\mathrm{a}}$

\begin{tabular}{|ll|r|r|r|r|r|}
\hline Model & & Sum of Squares & df & Mean Square & F & Sig. \\
\hline 1 & Regression & 26.970 & 5 & 5.394 & 12.906 & $.000^{\mathrm{b}}$ \\
& Residual & 24.240 & 58 & .418 & & \\
& Total & 51.209 & 63 & & & \\
\hline
\end{tabular}

a. Dependent Variable: Tobin's Q

b. Predictors: (Constant), LG_ROE, LN_TA, ESOP, V.K. D, ROA

Coefficients $^{\mathbf{a}}$

\begin{tabular}{|l|r|r|r|r|r|r|r|}
\hline \multirow{2}{*}{ Model } & \multicolumn{2}{|c|}{$\begin{array}{c}\text { Unstandardized } \\
\text { Coefficients }\end{array}$} & $\begin{array}{c}\text { Standardized } \\
\text { Coefficients }\end{array}$ & \multicolumn{1}{c|}{$\mathrm{t}$} & Sig. & \multicolumn{2}{|c|}{ Collinearity Statistics } \\
\hline & \multicolumn{1}{c|}{$\mathrm{B}$} & Std. Error & Beta & & & Tolerance & VIF \\
\hline 1 (Constant) & 4.545 & 2.223 & & 2.045 & .045 & & \\
ESOP & -.093 & .062 & -.152 & -1.496 & .140 & .793 & 1.261 \\
V.K. D & -.408 & .237 & -.211 & -1.721 & .091 & .542 & 1.847 \\
LN_TA & -.124 & .075 & -.197 & -1.644 & .106 & .567 & 1.763 \\
ROA & .117 & .029 & .528 & 4.093 & .000 & .491 & 2.038 \\
LG_ROE & -.229 & .260 & -.108 & -.882 & .382 & .549 & 1.823 \\
\hline
\end{tabular}

a. Dependent Variable: Tobin's Q 